\title{
Densitas Amfibi Di Pulau Lombok, Nusa Tenggara Barat
}

\author{
Muhammad Syazali $^{1}$, Agil Al Idrus ${ }^{2}$, Gito Hadiprayitno ${ }^{2}$ \\ ${ }^{1}$ Mahasiswa Program Studi Magister Pendidikan IPA Universitas Mataram \\ ${ }^{2}$ Dosen Program Studi Magister Pendidikan IPA Universitas Mataram \\ syazaliunram@gmail.com
}

\begin{abstract}
Abstrak.
Aspek ekologi dari amfibi dan trend populasi dari Limnonectes dammmermani yang belum banyak diketahui, disebabkan oleh kurangnya studi tentang hewan tersebut di habitatnya. Update data ukuran populasi spesies lainnya juga dibutuhkan untuk kegiatan konservasi amfibi di Pulau Lombok. Penelitian ini bertujuan untuk menganalisis densitas 12 spesies dari kelas amfibi yang ditemukan di Pulau Lombok. Survey lapangan dilakukan di 10 lokasi sampling yang tersebar di Pulau Lombok menggunakan metode Visual Encounter Survey (VES) selama bulan Maret - Juli 2016. Hasil penelitian menunjukkan bahwa Bufo melanostictus adalah spesies yang memiliki kepadatan paling tinggi (0.30 individu/are), kemudian Fejervarya cancrivora dan Limnonectes kadarsani (0.24 individu/are), sedangkan yang paling rendah adalah Oreophryne monticola (0.01 individu/are).
\end{abstract}

Kata kunci: densitas, amfibi, Pulau Lombok

\begin{abstract}
.
The ecological aspect of the amphibians and population trends of Limnonectes dammmermani are not widely known, due to the lack of studies of these animals in their habitats. Update data on other species population size is also required for amphibious conservation activities on Lombok Island. This study aims to analyze the density of 12 species of amphibian classes found on the island of Lombok. The field survey was conducted in 10 sampling sites spread on Lombok Island using Visual Encounter Survey (VES) during March - July 2016. The results showed that Bufo melanostictus was the highest density species (0.30 indi./are), then Fejervarya cancrivora and Limnonectes kadarsani (0.24 indi./are), while the lowest is Oreophryne monticola (0.01 indi./ are).
\end{abstract}

Key word: density, amphibians, Lombok Island 


\section{Pendahuluan}

Di habitatnya, amfibi dapat berfungsi sebagai konsumen sekunder atau tersier karena merupakan predator berbagai jenis serangga (Toft, 1981; Cogalnecianu et al., 2000; Rosa et al., 2002; Sole et al., 2005; Rodder et al., 2010), yang beberapa diantaranya adalah serangga hama dan vektor penyakit (Syazali, 2011). Xenohyla truncate dari Restinga de Marica, Brazil memakan buah sebagai salah satu sumber makanan (da Silva and de BrittoPereiera, 2006). Banyak dari spesies amfibi adalah mangsa bagi ular dan burung hantu (Clavero et al., 2005). Berudu sendiri adalah detritivor karena memanfaatkan serasah/debris dari tumbuhan sebagai sumber nutrisinya (Paul and Meyer, 2001). Larva dari beberapa spesies memakan mikroalga seperti peripiton, sehingga berfungsi sebagai konsumen primer (Dickman, 1968; Kupferberg, 1997).

Bagi manusia, amfibi dapat dimanfaatkan sebagai salah satu sumber makanan (Onadeko et al., 2011; Akinyemi and Ogaga, 2015), karena mengandung protein dan lemak (Oduntan et al., 2012; Ali et al., 2015). Indonesia sendiri bahkan pernah menjadi salah satu Negara eksportir paha katak terbesar di dunia (Niekisch,1986). Spesies yang bersifat edible adalah Fejervarya limnocharis, Fejervarya cancrivora dan Limnonectes macrodon (Kusrini and Alford, 2006). Di Sematera Barat, masyarakat memanfaatkan Hylarana erytraea sebagai obat tradisional (Hamdani, 2013).

Manfaat dari amfibi yang besar tersebut tidak berbanding lurus dengan upaya konservasi terhadap potensi keanekaragaman hayati tersebut (Iskandar and Erdelen, 2006). Fakta ini dapat dibuktikan dengan tidak adanya spesies dari kelas amfibi yang berstatus dilindungi UU (Kusrini, 2003; Ariza dkk., 2014), padahal terdapat spesies di Pulau Lombok yang terancam karena mengalami trend penurunan populasi (Iskandar et al., 1996; Iskandar and Mumpuni, 2004). Banyak dari aspek ekologi amfibi di Indonesia belum diketahui (Iskandar and Erdelen, 2006) karena studi tentang kelompok ini masih jarang (Kusrini, 2003).

Di Pulau Lombok sendiri, studi masih terbatas pada mengkaji struktur populasi tertentu (Fanani, 2010; Handayani, 2011) dan komunitas pada kawasan tertentu yang relatif sempit (Hijjati, 2011; Kadir, 2011). Survey yang terkait ukuran populasi dari masingmasing spesies di habitatnya belum pernah dilakukan. Faktor tersebut menyebabkan trend populasi dari Limnonectes dammermani bahkan belum diketahui (Iskandar and Mumpuni, 2004). Hal ini menunjukkan bahwa perlu adanya kegiatan penelitian, selain untuk menambah informasi tentang Limnonectes dammermani, update data ukuran populasi spesies lainnya juga dibutuhkan untuk kegiatan konservasi amfibi di Pulau Lombok.

\section{Bahan dan Metode}

Lokasi sampling

Penelitian dilakukan di Pulau Lombok. Sampel dikoleksi di 10 lokasi dengan membagi Pulau Lombok menjadi 3 bagian yaitu Utara, Tengah dan Selatan. Sepuluh lokasi sampling tersebut adalah Sekotong, TWA Kerandangan dan TWA Suranadi (Kabupaten Lombok Barat); Rembiga (Kota Mataram); Bunut Baok (Kabupaten Lombok Tengah); Sendang Gile (Kabupaten Lombok Utara); Hutan Lindung Kembang Kuning, Sembalu dan Lenek (Kabupaten Lombok Timur).

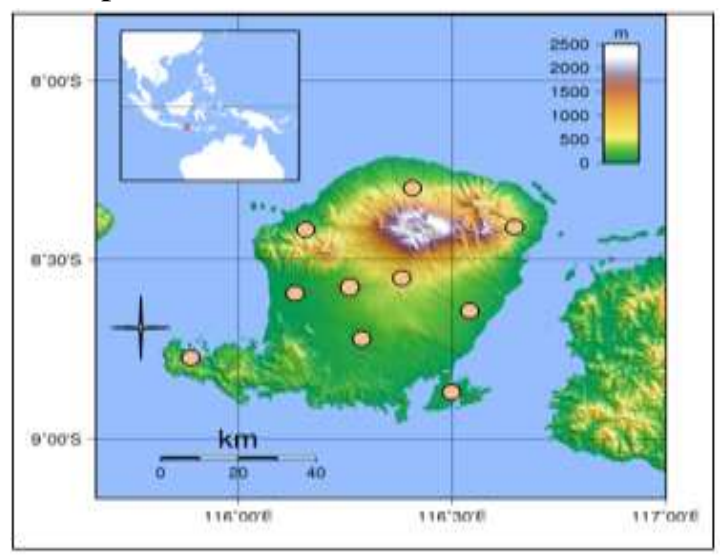

Gambar 1. Peta Lokasi Penelitian 
Metode sampling

Survey dilaksanakan pada kurun waktu bulan Maret - Juli 2016 menggunakan metode Visual Encounter Survey (VES) mengacu pada Heyer et al. (1994). Pada masing-masing lokasi sampling, ditentukan area jelajah berupa badan sungai dan sebelah kiri-kanan sungai mengacu pada Kusrini (2009).

Analisis data

Densitas spesies masing-masing amfibi diukur menggunakan persamaan yang mengacu pada Huang and Hou (2006):

$D_{i}=\frac{n_{i}}{A}$

Keterangan:

$D_{i}=$ densitas spesies i (individu/are)

$n_{i}=$ jumlah individu populasi i

$A=$ luas area cuplikan

\section{Hasil Penelitian}

Di Pulau Lombok terdapat 12 spesies dari kelas amfibi dengan ukuran populasi yang berbeda-beda. Spesies yang paling banyak ditemukan selama pengamatan adalah Bufo melanostictus (152 individu), diikuti oleh Fejervarya cancrivora, dan Limnonectes kadarsani (120 individu), dan yang paling sedikit adalah Oreophryne monticola sebanyak 5 individu. Spesies lain berkisar dari 12-81 individu (Tabel 1). Jumlah individu, jika ditinjau dari aspek komunitas di masingmasing lokasi sampling, maka yang terbesar adalah amfibi di TWA Suranadi (91 individu), kemudian amfibi di Lenek (81) individu, dan yang paling kecil adalah amfibi di Sendang Gile (35 individu). Komunitas amfibi di lokasi lain berkisar dari 47-76 individu (Tabel 1).

Luas total pengamatan amfibi adalah $50000 \mathrm{~m}^{2}$, atau setara dengan 500 are. Spesies yang memiliki kepadatan paling tinggi adalah Bufo melanostictus (0.304 individu/are), kemudian Fejervarya cancrivora dan Limnonectes kadarsani (0.24 individu/are), dan spesies dengan kepadatan paling rendah adalah Oreophryne monticola (0.01 individu/are). Spesies lainnya memiliki kisaran nilai 0.04 -
0.162 individu/are. Faktor, salah satu penyebabnya, adalah frekuensi kehadiran pada habitat yang lebih besar pada Bufo melanostictus, Fejervarya cancrivora dan Limnonectes kadarsani pada habitat dibandingkan dengan spesies yang lain. Faktor lain yang menjadi penyebabnya adalah populasinya yang besar di masing-masing habitat. Di sisi lain, Oreophryne monticola hanya ditemukan pada 1 lokasi penelitian (frekuensinya paling rendah) dan jumlah individu yang paling rendah pula (Tabel 1).

\section{Pembahasan}

Fenomena semakin meluasnya daerah urban memberikan luasan habitat yang lebih besar terhadap Bufo melanostictus yang berasosiasi kuat dengan aktivitas manusia manusia (Iskandar, 1998). Selain itu, kemampuannya dalam mengintroduksi habitat baru karena larvanya yang tahan terhadap pencemaran, menjadi faktor kunci "kesuksesan" spesies ini dalam memperbesar ukuran populasinya (Wijesinghe et al., 2011). Selain Bufo melanostictus, spesies Fejervarya cancrivora juga dapat hidup pada habitat yang terganggu oleh aktivitas manusia (Mistar, 2003). Spesies ini bahkan merupakan satu-satunya spesies yang dapat hidup di air payau (Gordon and Tucker, 1965). Kelebihann tersebut yang menyebabkannya dapat ditemukan di Danau Asin Gili Meno, sementara amfibi lain tidak ditemukan.

Limnonectes kadarsani adalah spesies yang paling besar ukuran populasinya di Pulau Lombok setelah Bufo melanostictus. Penyebabnya adalah distribusinya yang luas karena dapat tumbuh dan berkembang pada habitat dengan berbagai ketinggian, mulai dari hutan dataran rendah seperti TWA Kerandangan (Handayani, 2011; Kadir, 2011) sampai dengan hutan dataran tinggi di Gunung Rinjani (Iskandar, 1996). Sedangkan Oreophryne monticola yang memiliki ukuran populasi paling rendah hanya dapat ditemukan 
di Gunung Rinjani (Iskandar, 1998) dan di Pulau Bali (Kurniati dan Hamidy, 2014 )

Kepadatan spesies dari kelas amfibi di Pulau Lombok yang memiliki kisaran dari 0.01 sampai dengan 0.30 individu/are lebih kecil dibandingkan dengan yang ditemukan di Iberian Peninsula (Schall and Pianka, 1977). Di hutan Atlantik Brazil, Siquiera et al. (2009) melaporkan bahwa total amfibi yang ditemukan di area tersebut sebesar 107 individu dengan kepadatan spesies berkisar dari $0.2-4.0$ individu/are. Densitas yang lebih besar juga ditemukan di Mansoon Forest Taiwan (Huang and Hou, 2004). Kisaran nilainya adalah $3.5-10.2$ individu/are. Di Thailand, kepadatan amfibi memiliki kisaran dari 0.5 - 2.6 individu/are (Inger and Colwell, 1977). Di Pulau Iriomoto Jepang, kepadatan spesiesnya sangat tinggi yaitu mencapai 41.8 individu/are (Watanabe et al., 2005).

Faktor musim pengamatan yang berbeda menyebabkan adanya perbedaan tingkat kepadatan amfibi di benua Amerika. Kepadatan pada musim hujan sebesar 18.9 individu/are, sedangkan pada musim kemarau sebesar 14.0 individu/are di Osa, Kosta Rika. Di La Selva Kosta Rika dilaporkan bahwa densitasnya sebesar 21.4 individu/are pada musim hujan, dan 13.4 individu/are pada musim kemarau. Di San Vito Kosta Rika, kepadatan sebesar 62.3 individu/are pada musim hujan dan 55.1 pada musim kemarau (Scott, 1976). Faktor ketinggian yang berbeda di La Selva, Lieberman (1986) menemukan bahwa kepadatan amfibi sebesar 15.7 individu/are, sedangkan Heinen (1992) melaporkan 11.5 individu/are.

Perbedaan tersebut dapat juga disebabkan oleh faktor ketersediaan makanan seperti kelimpahan arthropoda (Toft, 1980), karakteristik populasi dari tiap-tiap spesies yaitu ada yang berjumlah besar seperti Limnonectes kadarsani (Handayani, 2011) dan ada pula yang ukuran populasinya kecil seperti Occidozyga sumatrana (Eto and Matsui, 2012), kerapatan vegetasi pada habitat (Inger and Colwell 1977) dan distribusi populasi pada kawasan (Rittenhouse and Semlitsch, 2007). Umumnya, faktor yang mempengaruhi dibedakan menjadi faktor internal dan faktor eksternal. Faktor internal merupakan faktor yang berasal dari populasi, sedangkan faktor eksternal adalah faktor yang berasal dari lingkungan dan mempengaruhi populasi.

\section{Kesimpulan}

Densitas dari 12 spesies amfibi yang ditemukan di Pulau Lombok adalah berkisar dari $0.01-0.30$ individu/are. Spesies yang memiliki densitas paling tinggi adalah Bufo melanostictus dan spesies yang memiliki densitas paling rendah adalah Oreophryne monticola.

\section{Daftar Pustaka}

Akinyemi, A.F., and Ogaga, R.D. 2015. Frog Consumption in Ibadan, Nigeria. Journal for Studies in Management and Planning 1(3): 522-531.

Ali, M.E., Naquiah, A.N., Mustafa, S., and Hamid, S.B.A. 2015. Differentiation of frog fats from vegetable and marine oils by Fourier Transform Infrared Spectroscopy and Chemometric Analysis. Croat. J. Food Sci. Technol. 7(1): 1-8.

Clavero, M., Prenda, J., and Delibes, M. 2005. Amphibian and Reptile Consumption by Otters (Lutra lutra) in a Coastal Area in Souther Iberian Peninsula. Herpetological Journal 15: 125-131.

Cogalnecianu, D., Palmer, M.W., and Ciubuc, C. 2000. Feeding in Anuran Communities on Islands in the Danube Oodplain. Amphibia-Reptilia 22: 1-19.

da Silva, H.R., and de Britto-Pereira, M.C. 2006. How Much Fruit do Fruit-eating Frogs Eat? An Investigation on the Diet of Xenohyla truncata (Lissamphibia: Anura: Hylidae). Journal of Zoology 270: 692-698.

Dickman, M. 1968. The Effect of Grazing by Tadpoles on the Structure of a Periphyton Community. Ecological Society of America 49(6): 1188-1190.

Eto, K., and Matsui, M. 2012. Field Observation of Egglaying Behavior of a Puddle Frog Occidozyga sumatrana 
from Bali, Indonesia (Anura: Dicroglossidae). Current Herpetology 31(2): 121-124.

Fanani, H. 2010. Struktur dan Keanekaragaman Gen Limnonectes kadarsani Di Lombok. Tesis S2. Universitas Gadjah Mada.

Gordon, M.S., and Tucker, V.A. 1965. Osmotic Regulation in the Tadpoles of the Crab-eating Frog (Rana cancrivora). J. Experimental Biol. 42: 437-445.

Handayani, M. 2011. Struktur Populasi Limnonectes kadarsani di TWA Kerandangan. Skripsi S1. Universitas Mataram.

Heinen, J.T. 1992. Comparisons of the Leaf Litter Herpetofauna in Abandoned Cacao Plantations and Primary Rain Forest in Costa Rica: some Implication for Faunal Restoration. Biotropica 24(3): 431-439.

Heyer, W.R., Donnelly, M.A., McDiarmid, R.W., Hayek, L.C., and Foster, M.S. 1994. Measuring and Monitoring Biological Diversity-Standar Methods for Amphibians. Washington DC: Smithhsonian Institution Press.

Hijjati, E. 2011. Keanekaragaman Amfibi (Ordo Anura) Di TWA Suranadi. Skripsi S1. Universitas Mataram.

Huang, C.Y., and Hou, P.C.L. 2004. Density and Diversity of Litter Amphibians in a Mnsoon Forest of Southern Taiwan. Zoological Studies 43(4): 795-802.

Inger, R.F., and Colwell, R.K. 1977. Organization of Contiguous Communities of Amphibians and Reptiles and Thailand. Ecological Monographs 47(3): 229-253.

Iskandar, D.T., Boeadi, and Sancoyo, M. 1996. Limnonectes kadarsani (Amphibia: Anura: Ranidae), a New Frog from the Nusa Tenggara Ilands. The raffles Bulletin of Zoology 44: 21-28.

Iskandar, D.T. 1998. The Amphibians of Java and Bali. Jakarta: Pusat penelitian dan Pengembangan Biologi LIPI.

Iskandar, D.T., and Mumpuni. 2004. Limnonectes dammermani. The IUCN Red List of Threatened Species. (online). $\quad$ www.iucnredlist.org. Didownload pada tanggal 4 Maret 2014.

Iskandar, D.T., and Erdelen, W.R. 2006. Conservations of Amphibians and
Reptiles In Indonesia: Issues and Problems. Amphibian and Reptile Conservation 4(1): 60-87.

Kadir, A. 2011. Keanekaragaman Spesies Amfibi di TWA Kerandangan. Skripsi S1. Universitas Mataram.

Kupferberg, S. 1997. Facilitation of Periphyton Production by Tadpole Grazing: Functional Differences between Species. Freshwater Biology 37: 427-439.

Kurniati, H., dan Hamidy, A. 2014. Karakteristik Suara Kclompok Kodok Microhylidae Bertubuh Kccil Asal Bali (Anura: Microhylidae). Jurnal Biologi Indonesia 10(2): 159-167.

Kusrini, M.D. 2003. Predicting the Impact of the Frog Leg Trade in Indonesia: An Ecological View of the Indonesian Frog Leg Trade, Ephasizing Javanese Edible Frog Species. Bogor: Fakultas Kehutanan IPB Bogor.

Kusrini, M.D. 2009. Pedoman Penelitian dan Survey Amfibi di Alam. Bogor: Fakultas Kehutanan IPB.

Lieberman, S.S. 1986. Ecology of the Leaf Litter Herpetofauna of a Neotropical Rainforest: La Selva Costa Rica. Acta Zoologica Mexicana 15(1): 1-71.

Mistar. 2003. Panduan Lapangan Amfibi Kawasan Ekosistem Leuser. Bogor: The Gibbon Foundation dan PILI-NGO Movement.

Niekisch, M. (1986). The International Trade in Frogs Legs. Traffic Bulletin 8(1): 710

Oduntan, O.O., Soaga, J.A., and Jenyo-Oni, A. 2012. Comparison of Edible Frog (Rana esculenta) and Other Bush Meat Types: Proximate Composition, Social Status and Acceptability. Journal Environmental Research and Management 3(7): 124-128.

Onadeko, A.B., Egonmwan, R.I., and Saliu, J.K. 2011. Edible Amphibian Species: Local Knowledge of their Consumption in Southwest Nigeria and their Nutritional Value. West African Journal of Applied Ecology 19: 67-76.

Paul, M.J., and Meyer, J.L., 2001. Streams in the Urban Landscape. Annual Review of Ecology and Systematics 32: 333-365.

Rittenhouse, T.A., and Semlitsch, R.D. 2007. Distribution of Amphibians in 
Terrestrial Habitat Surrounding Wetlands. Wetlands 27(1): 153-161.

Rodder, D., Lima, J.E de Paula., and Sole, M. 2010. Diet of Two Sympatric Phyllomedusa (Anura: Hylidae) Species from a Cacao Plantation in Southern Bahia, Brazil. North-Western Journal of Zoology 6(1): 13-24.

Rosa, I., Canavero, A., Maneyro, R., Naya, D.E., and Camargo, A. 2002. Diet of Four Sympatric Anura Species in a Temperate Environment. Biol. Sol. Zool. 13: 12-20.

Schall, J.J., and Pianka, E.R. 1977. Species Densities of Reptiles and Amphibians on the Iberian Peninsula. Acta Vertebrata 4: 27-34.

Scott, N.J. 1976. The Abundance and Diversity of the Herpetofauna of Tropical Forest Litter. Biotropica 8(1): 41-58.

Siqueira, C.C., Vrcibradic, D., AlmeidaGomes, M., Borges-Junior, V.N.T., Almeida-Santos, P., Almeida-Santos, M., Ariani, C.V., Guedes, D.M., Goyannes-Araujo, P., Dorigo, T.A., Sluys, M.V., and Rocha, C.F.D. 2009. Density and Richness of Leaf Litter Frogs (Amphibia: Anura) of an Atlantic Rainfores Area in the Serra dos Orgaos, Rio de Janeiro State, Brazil. Zoologia 26(1): 97-102.

Sole, M., Beckmann, O., Pelz, B., Kwet, A., and Engels, W. Stomach-flushing for Diet Analysis in Anurans: an Improved Protocol Evaluated in a Case Study in Araucaria Forests, Southern Brazil. Studies on Neotropical Fauna and Environment 40(1): 23-28.

Syazali, M. 2011. Identifikasi Spesies yang Dimakan Kodok Rumah (Bufo melanostictus) dan Peranannya sebagai Pengendali Serangga Hama dan Vektor Penyakit. Skripsi S1. Universitas Mataram.

Toft, C.A. 1981. Feeding Ecology of Panamanian Litter Anurans: Patterns in Diet and Foraging Mode. Journal of Herpetology 15(2): 139-144.

Watanabe, S., Nakanishi, N., and Izawa, M. 2005. Seasonal Abundance in the Floor Dwelling Frog Fauna on Iriomote Island of the Ryuku Archipelago, Japan. Journal of Tropical Ecology 21(1): 8591. 